\title{
PENGARUH DISIPLIN KERJA TERHADAP KINERJA GURU
}

\author{
Rabukit Damanik \\ Dosen STKIP Budi Daya Binjai
}

\begin{abstract}
ABSTRAK
Pendidikan adalah proses pelatihan dan pengembangan pengetahuan, ketrampilan, fikiran, karakter dan seterusnya, khususnya lewat persekolahan formal. Pemahaman pada pendidikan mengacu kepada konsep tersebut menggambarkan bahwa pendidikan memiliki sifat dan sasaran yaitu manusia. Tujuan penelitian ini adalah untuk mengetahui: pengaruh disiplin kerja terhadap kinerja guru. Metode penelitian ini adalah penelitian kuantitatif dengan desain expost facto. Sampel penelitian ini adalah guru SMA Negeri Kabupaten Deli Serdang sebanyak 108 orang. Hasil penelitian ini menunjukkan ada engaruh disiplin kerja terhadap kinerja guru sebesar $0,288=28,8 \%$, hal ini terlihat pada nilai Sig. $0,00(0,04$ $<0,05$.
\end{abstract}

\section{Kata Kunci : Disiplin, Kerja, Kinerja, dan Guru}

\section{A. PENDAHULUAN}

Pendidikan adalah proses pelatihan dan pengembangan pengetahuan, ketrampilan, fikiran, karakter dan seterusnya, khususnya lewat persekolahan formal. Pemahaman pada pendidikan mengacu kepada konsep tersebut menggambarkan bahwa pendidikan memiliki sifat dan sasaran yaitu manusia. Manusia itu sendiri memiliki banyak aspek dan sifatnya yang sangat kompleks, Misalnya saja manusia memiliki sifat "timbal-balik" artinya dia akan cenderung bekerja dengan baik apabila diberi imbalan yang sangat patut. Manusia juga memiliki sifat disiplin diri, manusia juga memiliki sifat "Pengawasan" artinya harus diawasi untuk memperoleh hasil kerja yang maksimal. contoh.: Contoh sifat manusia diatas memiliki pengaruh terhadap kinerja manusia tersebut. Masing-masing manusia memiliki perbedaan sifat dan sikap, perberdaan tersebut dipengaruhi oleh orientasi, filsafat hidup dan latar belakang kehidupan manusia tersebut.
Menurut Sagala (2007) dalam pendidikan, faktor guru adalah yang sangat penting untuk mewujudkan tercapainya tujuan pendidikan yang telah ditetapkan dan akan dicapai, sehingga kinerja guru adalah hal yang sangat penting untuk mencapai tujuan pendidikan tersebut. Semakin baik kinerja guru semakin baik pula mutu pendidikan demikian pula sebaliknya semakin buruk kinerja guru semakin buruk pula mutu pendidikan yang diperoleh. "Kinerja“ dalam bahasa Indonesia adalah terjemahan dari kata bahasa Inggris, yaitu kata "Performance" yang berarti : (1) pekerjaan, perbuatan, (2) penampilan, pertunjukan. Arti lain dari kinerja adalah sebagai ukuran kesuksesan dalam pencapaian tujuan yang telah ditetapkan sebelumnya.

Komariah dan Triatna (2006) Kinerja Sekolah ditunjukan oleh ukuran-ukuran tentang bagaimana warga sekolah merasakan hal-hal seperti kemanfaatannya, kepastiannya, keadilannya, kondisi kerjanya, kesan dari staf terhadap atasannya, koleganya, peluang untuk maju, 


\section{Jurnal Serunai Ilmu Pendidikan \\ Vol.5, No.2, Desember 2019 \\ e-ISSN 2621 - 2676}

pengembangannya, keselamatan, keamanannya dan pemberian imbalan. Kinerja guru adalah tampilan kerja guru. Ada 11 indikator kinerja yang dapat dinilai yaitu : (1) kesetiaan, (2) prestasi kerja, (3) kejujuran, (4) kedisiplinan, (5) kreatifitas, (6) kerja sama, (7) kepemimpinan, (8) kepribadian, (9) prakar- sa, (10) kecakapan dan (11) tanggung jawab. Idealnya seorang guru dapat dikatakan memiliki kinerja yang baik jika : (1) guru tersebut memiliki kesetiaan terhadap negara, pimpinan yang benar, tugasnya dan kesetiaan kepada masyarakat (2) guru tersebut memiliki prestasi kerja yang baik, selalu ingin meningkatkan kemampuan,meningkatkan etos kerja dan semangat kerja yang tinggi (3) guru tersebut memiliki rasa kejujuran yang tinggi dan dapat diaplikasikan dalam setiap sendi kehidupan ataupun dalam setiap urusan (4) guru tersebut harus memiliki kedisiplinan yang tinggi tepat waktu masuk dan keluar dalam mengajar, tepat waktu dalam menyelesaikan seluruh administrasi guru dan menyelesaikan seluruh tugas yang berkenaan dengan keguruannya dengan cepat dan tepat (5) guru tersebut harus memiliki kreatifitas yang tinggi, mampu berinovasi, sehingga siswa tidak mengalami kebosanan selama proses pembelajaran. (6) guru tersebut harus memiliki kerja sama yang baik dengan sesama guru, orang tua murid dan pimpinan disekolah (7) guru tersebut harus memiliki watak kepemimpinan yang baik sehingga para siswa merasa nyaman dibawah kepemimpinan guru tersebut, yaitu memiliki sifat yang adil, bijak sana dan penyayang pada anak didiknya (8) guru tersebut harus memiliki kepribadian yang positif atau kepribadian yang baik. Kepribadian yang baik adalah kepribadian yang dapat menjadi teladan, terbuka, menghargai orang lain dan terus belajar untuk pengembangan dirinya (9) guru harus memiliki prakarsa untuk menyampaikan gagasangagasan demi kemajuan sekolah (10) guru tersebut harus memiliki kecakapan hidup, memiliki kompetensi pedagogik, kompetensi kepribadian dan kompetensi sosial, hal ini akan sangat membantu guru dalam melaksanakan tugasnya dan (11) guru tersebut juga harus memiliki tanggung jawab atas apa yang telah dilakukannya baik tanggung jawab terhadap atasan, terhadap bangsa maupun terhadap Tuhan Yang Maha Esa.

Bertolak dari pendapat para ahli diatas maka yang dimaksud dengan kinerja guru adalah prestasi kerja (performance) adalah merupakan hasil yang dicapai oleh guru dalam melaksanakan tugas-tugas yang dibebankan kepadanya yang didasrkan atas kecakapan, pengalaman dan kesungguhan serta waktu dengan output yang dihasilkan tercermin baik.

$$
\text { Menurut Sedarmayanti (2001) kinerja }
$$
guru dipengaruhi antara lain : (1) sikap mental (motivasi kerja, disiplin kerja, etika kerja); (2) pendidikan, (3) keterampilan, (4) manajemen kepemimpinan; (5) tingkat penghasilan, (6) gaji dan kesehatan; (7) jaminan sosial; (8) iklim kerja; (9) sarana prasarana; (10) teknologi; (11) kesempatan berprestasi.Sedangkan Sutikno (2006) menyatakan ada beberapa faktor yang mempengaruhi kinerja yaitu : (1) sikap mental yang meliputi motivasi kerja, disiplin kerja dan etika kerja, (2) pendidikan, (3) manajemen, (4) keterampilan, (5) penghasilan, (6) gizi dan kesehatan, (7)jaminan sosial, (8) tekhnologi, (9) kesempatan berprestasi dan (10) iklim kerja. 


\section{Jurnal Serunai Ilmu Pendidikan \\ Vol.5, No.2, Desember 2019 \\ e-ISSN 2621 - 2676}

Salah satu yang dapat mempengaruhi kinerja guru adalah disiplin kerja. Disiplin merupakan arahan untuk melatih dan membentuk seseorang melakukan sesuatu menjadi lebih baik. Disiplin juga merupakan suatu sikap prilaku dan perbuatan yang sesuai dengan peraturan baik tertulis maupun tak tertulis mengingat begitu pentingnya masalah disiplin ini demi peningkatan kinerja, untuk itu perlu dicari dimana sebenarnya letak disiplin. Secara singkat dapat dikatakan bahwa sumber disiplin adalah adanya kesadaran dalam melaksanakan tugas atau pekerjaannya (Anoraga, 1998:47). Disiplin sangat penting untuk kemajuan sekolah, digunakan terutama untuk memotivasi guru agar dapat mendisiplinkan diri dalam melaksanakan pekerjaan baik secara perorangan maupun kelompok, disamping itu disiplin bermamfaat mendidik guru untuk mematuhi dan menyenangi peraturan, prosedur maupun kebijakan yang ada sehingga dapat menghasilkan kinerja yang baik.

Kedisiplinan adalah suatu sikap, prilaku, atau perbuatan yang sesuai dengan peraturan yang telah ditetapkan misalnya saja : menurut peraturan masuk mengajar 07. ${ }^{30} \mathrm{WIB}$, maka guru tersebut harus datang sebelum pukul 07. ${ }^{30}$ WIB. Seorang guru dikatakan memiliki disiplin apabila melaksanakan seluruh pekerjaan dan tugasnya sesuai daengan peraturan yang telah ditetapkan. Demikian juga sebaliknya seorang guru dikatakan tidak memiliki disiplin apabila guru tersebut tidak mematuhi peraturan yang telah ditetapkan. Oleh sebab itulah kedisiplinan menpengaruhi kinerja. Disiplin yang tinggi akan menimbulkan kinerja yang tinggi, dan disiplin yang rendah akan mengakibatkan kinerja yang rendah.

\section{B. Landasan Teoritis}

\section{Kinerja guru}

Pada hakikatnya kinerja merupakan prestasi yang dicapai oleh seseorang dalam melaksanakan tugasnya atau pekerjaannya sesuai dengan standar dan kriteria yang ditetapkan untuk pekerjaan itu. Menurut Gibson (1990) mengemukakan bahwa kinerja merujuk kepada tingkat keberhasilan dalam melaksanakan tugas serta kemampuan untuk mencapai tujuan yang telah ditetapkan artinya kinerja dikatakan baik atau sukses jika tujuan yang diinginkaaan dapat tercapai dengan baik. Sedangkan Wahyu Sumijo (2007) mengartikan kinerja secara kualitatif dan kuantitatif yang terukur dalam rangka membantu tercapainya tujuan kelompok dalam suatu unit kerja.

Berbicara tentang kinerja guru akan terkait dengan faktor-faktor pembentuknya baik secara langsung maupun tidak langsung, baik secara internal maupun secara eksternal. Hal ini sebagaimana yang dijelaskan oleh Timpe dalam Mangkunegara (2007). faktor-faktor kinerja terdiri dari faktor internal dan faktor eksternal. Faktor internal (disposisional) yaitu faktor yang dihubungkan dengan sifat-sifat seseorang. Misalnya, kinerja seseorang baik, disebabkan karena mempunyai kemampuan tinggi dan type pekerja keras, sedangkan seseorang mempunyai kinerja jelek disebabkan orang tersebut mempunyai kemampuan rendah dan tidak memiliki upayaupaya untuk memperbaiki kemampuannya. Faktor eksternal yaitu faktor-faktor yang mempengaruhi kinerja seseorang yang berasal dari lingkungan, seperti perilaku, sikap dan tindakan-tindakan rekan 


\section{Jurnal Serunai Ilmu Pendidikan \\ Vol.5, No.2, Desember 2019 \\ e-ISSN 2621 - 2676}

kerja, bawahan atau pimpinan, fasilitas kerja dan iklim organisasi.

Faktor internal dan faktor eksternal ini merupakan kontribusi yang mempengaruhi kinerja akibat psikologis dan berdasarkan kepada tindakan. Seseorang karyawan yang menganggap kinerjanya baik berasal dari faktor-faktor internal seperti kemampuan atau upaya diduga orang tersebut akan mengalami lebih banyak perasaan positif tentang kinerjanya dibandingkan dengan jika ia tidak memiliki upaya atau kemampuan yang baik. Sedangkan menurut Gibson, dkk (1985) meliputi variabel individu, antara lain: kemampuan keterampilan, kemampuan mental dan latar belakang keluarga tingkat sosial, pengalaman dan demografi. Variabel Individu terdiri dari sumber daya, kepemimpinan, imbalan, struktur dan desain pekerjaan. Variabel psikologis meliputi persepsi, sikap, sikap kepribadian belajar dan inovasi.

Hasibuan (2005) menyebutkan ada 11 indikator kinerja dapat dinilai dari unsur : kesetiaan, prestasi kerja, kejujuran, kedisiplinan, kreatifitas, kerjasama, kepemimpinan, kepribadian, prakarsa, kecakapan dan tanggung jawab dihubungkan dengan guru maka indikator kinerja guru meliputi beberapa komponen yaitu suatu kegiatan persiapan awal sebelum suatu kegiatan dilaksanakan secara sungguh dengan penuh pertimbangan dan penalaran sehingga pekerjaan dapat dilaksanakan secara efektif dan efisien. Nursito (2002:5) mengatakan salah satu kinerja mengajar guru adalah kemampuan dalam membuat perencanaan mengajar misalnya kesiapan administrasi, kemampuan membaca kurikulum, pengayaan materi ajar, pembekalan peningkatan, pemantapan study; 2) penguasaan materi, guru harus menguasai bahan dan bidang yang menjadi tugasnya. Materi / bahan pelajaran harus dikuasai secara benar, guru harus mengerti bagaimana metode ilmu yang diajarkan, guru perlu mengerti bagaimana cara kerja ilmu yang digeluti, dengan demikian akan memudahkan dalam menjelaskan kepada anak-anak dan guru akan lebih baik jika mengetahui bagaimanaa para ahli menemukan rumus, hukum, dalil-dalil.

Senada dengan yang dikemukakan oleh Suparno (2003) mengemukakan bahwa guru harus memiliki kemampuan menguasai materi pelajaran. Penguasaan yang dimaksudkan adalah kemampuan dalam penguasaan bahan dari setiap mata pelajaran yang diampuhnya dan pendalaman perpustakaan sehingga dapat menjadi informator dan sumber informasi kegiatan pembelajaran. Kemampuan dalam penguasaan pembelajaran adalah kemampuan dalam bidang study yang memuat pemahaman akan karakteristik dan isi bahan ajar menguasai konsep mengenal metode ilmu yang bersangkutan memahami konteks bidang itu dalam kaitannya dengan masyarakat, lingkungan dan dengan ilmu lain.

Oleh karena itu, guru tidak cukup hanya mendalami ilmunya tetapi termasuk bagaimana dampak dan hubungan ilmu itu dalam hidup masyarakat dan ilmu-ilmu yang lain. Sehingga guru diharapkan punya wawasan yang luas, mengerti bagaimana metodologi, mengerti konteks ilmu yang mau diajarkannya, mau terus belajar dan selalu ingin berkembang, guru yang menguasai bahan ilmu tentunya tidak akan pernah berhenti untuk belajar, terlebih untuk bidang ilmunya. guru tidak akan puas dengan pengetahuannya, tetapi terus mengembangkannya. 


\section{Jurnal Serunai Ilmu Pendidikan \\ Vol.5, No.2, Desember 2019 \\ e-ISSN 2621 - 2676}

oleh sebab itu, guru penting untuk belajar sepanjang hayatnya.

\section{Disiplin Kerja}

Disiplin sangat penting untuk pertumbuhan organisasi, digunakan terutama untuk memotivasi guru agar dapat mendisiplinkan diri dalam melaksanakan pekerjaan baik secara perorangan maupun kelompok. Disamping itu disiplin bermanfaat mendidik guru untuk mematuhi dan menyenangi peraturan, prosedur, maupun kebijakan yang ada, sehingga dapat menghasilkan kinerja yang baik.

Menurut Rivai (2004) mengartikan disiplin kerja sebagai suatu alat yang digunakan oleh para pimpinan untuk berkomunikasi dengan bawahan agar mereka bersedia untuk mengubah suatu perilaku serta sebagai upaya untuk meningkatkan kesadaran dan kesediaan seseorang mentaati semua peraturan dan norma-norma sosial yang berlaku. Sedangkan Hasting (1999) menyatakan disiplin kerja merupakan arahan untuk melatih dan membentuk seseorang melakukan sesuatu menjadi lebih baik. Disiplin adalah suatu proses yang dapat menumbuhkan perasaan seseorang untuk mempertahankan dan meningkatkan tujuan organisasi secara obyektif, melalui kepatuhannya menjalankan peraturan serta ketentuan organisasi.

Dalam rangka menumbuh-kembangkan disiplin kerja sehagaimana yang diharapkan, seorang pemimpin harus menerapkan prinsipprinsip disiplin sebagaimana dikemukakan Subekti (2008) meliputi: (1). Pemimpin mempunyaii prilaku positif; Untuk dapat menjalankan disiplin yang baik dan benar, seorang pemimpin harus dapat menjadi model/panutan bagi bawahannya. Oleh karena itu seorang pimpinan harus dapat mempertahankan perilaku yang positif sesuai dengan harapan staf, (2). Penelitian yang cermat : Dampak dari tindakan indisipliner cukup serius, pimpinan harus memahami akibatnya. Data dikumpulkan secara faktual, dapatkan informasi dari staf yang lain, tanyakan secara pribadi rangkaian pelanggaran yang telah dilakukan, analisa, dan bila perlu minta pendapat dari pimpinan lainnya, (3). Kesegeraan; Pimpinan harus peka terhadap pelanggaran yang dilakukan oleh bawahan sesegera mungkin dan harus diatasi dengan cara yang bijaksana. karena, bila dibiarkan menjadi kronis, pelaksanaan disiplin yang akan ditegakkan dapat dianggap lemah, tidak jelas, dan akan mempengaruhi hubungan kerja dalam organisasi tersebut, (4).Lindungi Kerahasiaan (privacy); Tindakan indisipliner akan mempengaruhi ego staf, oleh karena itu akan lebih baik apabila permasalahan didiskusikan secara pribadi, pada ruangan tersendiri dengan suasana yang rileks dan tenang kerahasiaan harus tetap dijaga karena mungkin dapat mempengaruhi masa depannya, (5). Fokus pada masalah; Pimpinan harus dapat melakukan penekanan pada kesalahan yang dilakukan bawahan dan bukan pada pribadinya, kemukakan bahwa kesalahan yang dilakukan tidak dapat dibenarkan, (6). Peraturan dijalankan secara konsisten; Peraturan dijalankan secara konsisten, tanpa pilih kasih. Setiap pegawai yang bersalah harus dibina sehingga mereka tidak merasa dihukum dan dapat menerima sanksi yang dilakukan secara wajar, (7). Fleksibel; Tindakan disipliner ditetapkan apabila seluruh informasi tentang pegawai telah di analisa dan 


\section{Jurnal Serunai Ilmu Pendidikan \\ Vol.5, No.2, Desember 2019 \\ e-ISSN 2621 - 2676}

dipertimbangkan. Hal yang menjadi pertimbangan antara lain adalah tingkat kesalahannya, prestasi pekerjaan yang lalu, tingkat kemampuannya dan pengaruhnya terhadap organisasi., (8). Mengandung Nasihat; Jelaskan secara bijaksana bahwa pelanggaran yang dilakukan tidak dapat diterima. File pegawai yang berisi catatan khusus dapat digunakan sebagai acuan, sehinga mereka dapat memahami kesalahannya., (9). Tindakan Konstruktif; Pimpinan harus yakin bahwa bawahan telah memahami perilakunya bertentangan dengan tujuan organisasi dan jelaskan kembali pentingnya peraturan untuk staf maupun organisasi. Upayakan agar staf dapat merubah perilakunya sehingga tindakan indisipliner tidak terulang lagi., (10). Follow Up (Evaluasi); Pimpinan harus secara cermat mengawasi dan menetapkan apakah perilaku bawahan sudah berubah. Apabila perilaku bawahan tidak berubah, pimpinan harus melihat kembali penyebabnya dan mengevaluasi kembali batasan akhir tindakan indisipliner.

Commings (1984) dapat dilakukan melalui dua cara, yaitu: (1) Preventive dicipline merupakan tindakan yang diambil untuk mendorong para pekerja mengikuti atau mematuhi norma-norma dan aturan-aturan sehingga pelanggaran tidak terjadi. Tujuannya adalah untuk mempertinggi kesadaran pekerja tentang kebijaksanaan dan peraturan pengalaman kerjanya. (2) Corrective discipline merupakan suatu tindakan yang mengikuti pelanggaran dari aturan-aturan, hal tersebut mencoba untuk mengecilkan pelanggaran lebih lanjut sehingga diharapkan untuk prilaku dimasa mendatang dapat mematuhi normanorma peraturan.

\section{Metode Penelitian}

Metode penelitian ini adalah penelitian kuantitatif dengan desain expost facto.. Populasi dalam penelitian ini adalah seluruh guru SMA Negeri Kabupaten Deli Serdang sebanyak 1080 Orang. Sedangkan sampel berjumlah 108 orang.

Data yang diperoleh dianalisis dengan menggunakan teknik statistik yakni uji persyaratan analisis data dan pengujian hipotesi. Dalam hal ini menggunakan bantuan komputer program SPSS 16.

\section{HASIL PENELITIAN DAN PEMBAHASAN}

Berdasarkan butir-butir pernyataan variabel kinerja guru yang berjumlah 34 butir, maka skor terendah adalah 64 dan yang tertinggi adalah 107 . Rata-rata 92,02; simpangan baku 12,51; median 91,46; dan modus 88,17. Sebaran data ini menunjukkan bahwa skor rata-rata, median dan modus tidak jauh berbeda, hal ini menunjukkan bahwa sebaran data cenderung berdistribusi normal.. Sedangkan berdasarkan butir-butir pernyataan variabel disiplin kerja yang berjumlah 30 butir, maka skor terendah adalah 58 dan yang tertinggi adalah 112. Rata-rata 91,39; simpangan baku 14,12; median 90,50; dan modus 89,96. Sebaran data ini menunjukkan bahwa skor rata-rata, median dan modus tidak jauh berbeda, hal ini menunjukkan bahwa sebaran data cenderung berdistribusi normal.

Berdasarkan hasil analisa data diketahui pengaruh disiplin kerja terhadap kinerja guru sebesar $0,288=28,8 \%$. Untuk menguji apakah pengaruh disiplin kerja terhadap kinerja guru tersebut signifikan atau tidak, maka berdasarkan 
hasil pengujian terlihat bahwa pada kolom Sig (signifikan) pada tebel Coefficients diatas didapat nilai Sig $0,00(0,05>0,00)$. Hasil penelitian menunjukkan bahwa disiplin kerja secara langsung mempengaruhi kinerja guru, artinya jika guru mempunyai disiplin kerja tinggi cenderung memiliki kinerja tinggi. Temuan penelitian ini didukung oleh hasil penelitian Aritonang, Keke, T. (2005) tentang Kompensasi, Disiplin Kerja Guru dan Kinerja Guru SMP Kristen BPK Penabur Jakarta.

Dari temuan penelitian menunjukkan bahwa faktor disiplin kerja sangat mempengaruhi kinerja seseorang dalam hal ini kinerja guru. Menurut Nitisemito (1991) yang mengartikan disiplin sebagai suatu sikap, perilaku dan perbuatan yang sesuai dengan peraturan dari perusahaan, baik tertulis maupun tidak tertu1is. Sedangkan menurut Commings (1984) dapat dilakukan melalui dua cara, yaitu: (1) Preventive dicipline merupakan tindakan yang diambil untuk mendorong para pekerja mengikuti atau mematuhi norma-norma dan aturan-aturan sehingga pelanggaran tidak terjadi. Tujuannya adalah untuk mempertinggi kesadaran pekerja tentang kebijaksanaan dan peraturan pengalaman kerjanya. (2) Corrective discipline merupakan suatu tindakan yang mengikuti pelanggaran dari aturan-aturan, hal tersebut mencoba untuk mengecilkan pelanggaran lebih lanjut sehingga diharapkan untuk prilaku dimasa mendatang dapat mematuhi norma-norma peraturan.

\section{E. Penutup}

Berdasarkan data dan hasil analisis yang telah dipaparkan diatas, dapat ditarik kesimpulkan sebagai berikut: Terdapat pengaruh yang signifikan antara disiplin kerja terhadap kinerja guru sebesar $28,8 \%$. Saran-saran yang disampaikan sehubungan dengan temuan penelitian ini adalah sebagai berikut: 1) melakukan pembinaan terhadap guru dalam melaksanakan tugas dan tanggung jawabnya, dan 2) membuka kesempatan pada guru untuk melanjutkan pendidikannya pada jenjang yang lebih tinggi dengan bea siswa tanpa membedakan kelompok keilmuan misalnya eksakta atau non eksakta.

\section{DAFTAR PUSTAKA}

Anoraga, Pandji. 1998. Psikologi Kerja. Jakarta : Rineka Cipta

Aritonang, Keke, T. 2005. Kompensasi Kerja, Disiplin Kerja, Kinerja Guru dan Kinerja Guru SMP Kristen BPK Penabur Jakarta. Jakarta : Jurnal Pendidikan PenaburNo.04/Th.IV/Juli 2005.

Gibson, D. and Jon M.Ivancevich. 1990. Managemen terjemahan. Jakarta : Erlangga.

Hasibuan, Malayu S. P, (2007). Manajemen Sumber Daya Manusia. Jakarta: Bumi Aksara.

Mangkunegara, Anwar Prabu. 2001. Manajemen Sumber Daya Manusia Perusahaan : EdisiKetiga. Bandung : PT. Remaja Rosdakarya.

Nitisemito, Alex S. 1991. Manajemen Personalia. Jakarta: Galia Indonesia.

Sagala, 2007. Manajemen Strategik dalam Peningkatan Mutu Pendidikan. Bandung : Alfabeta. 
2009. Kemampuan Profesional Guru dan Tenaga kependidikan. Bandung : Alfabeta.
Rivai, Veithzal. 2005. Perpormance Appraisal. Jakarta : Raja Grafindo Parsada.

Wahyu Sumijo. 2007. Kepemimpinan Kepala Sekolah. Jakarta : Raja Grafindo Persada. 